\title{
UNSATURATED SEEPAGE BEHAVIOR STUDY USING SOIL COLUMN TEST
}

\author{
D.H. KIM \\ Griffith School of Engineering, Griffith University, Australia, donghyun.kim3@griffithuni.edu.au \\ S.K. KIM \\ Dongguk University, South Korea, skkimgeo@kornet.net \\ I. GRATCHEV \\ Griffith School of Engineering, Griffith University, Australia, i.gratchev@griffith.edu.au
}

\begin{abstract}
The occurrence of shallow rainfall-induced landslides can be attributed to a rapid rise of ground water table. The primary objective of this work is an experimental and numerical investigation on the development of perched water table in prolonged rainfall condition. Column infiltration tests were conducted to observe the progression of the wetting front over time in both drained and undrained conditions. Measurements taken during the column infiltration tests included water contents, matric suctions and pore water pressure heads. Results show that the rapid increase in positive pore-water pressure was observed during the advance of the wetting front, suggesting the development of a perched water table within the column. Finite element analyses, which were carried out to compare with the experimental data, were consistent with the results obtained from the column tests.
\end{abstract}

\section{INTRODUCTION}

Rainfall-induced landslides area common form of slope failure in residual soil areas.In this case, heavy rain fall is the main reason for the failure, and it occurs in the unsaturated zone formed over the bed rock in the slope [9]. Some studies have dealt with the effect of rainfallon the slope stability during the process of infiltration.Alonso [1] carried out numerical analyses on rainfalltriggered infiltration with a variety of soils ranging from siltysand to clay. It was noted that the delay of infiltration in the bottom layer induced a temporary ground water table and increased pore water pressure, causing a dramatic reduction in the factor of safety.From a strength point of view, Fredlund and Krahn[8]showed that the stability of the near-surface portion of a slope is considerably responsive to changes in cohesion. Becausethe dissipation of the negative water pressure can give rise to the loss of cohesive strength of the soil,rainfall can lead to a considerable decrease in the safety factor of slopes. Additionally, rainfall-induced slope failuresdepend heavily on the relationship between water content and suction in unsaturated soils and is related with unsaturated conductivity functions as well as the intensity of rainfall.

The purpose of this study is to investigate the infiltration behavior and development of temporary ground water tables over a bed rock interface. For the experimental part of this study, the column tester was developed. It can measure water content, suction and pore water pressure with the propagation of wetting front. Numerical analyses using the seepage finite element code SEEP/W (Geostudio, 2004)[6]were also performed to studythe saturated/unsaturated infiltration behavior and compare the experimentaldata with the analysis results. 


\section{EXPERIMENTAL STUDY}

\section{APPARATUS}

The infiltration tests were conducted in a soil column apparatus. Thisapparatus was fabricated from an acrylic mold of $200 \mathrm{~mm}$ inside diameter and 1,000 $\mathrm{mm}$ in overall length. The column comprised five separated parts of cylindrical sections toplace three kinds of equipment (a Jet fill tensiometer, a gypsum block and a porous tip) on each part of columnand to keep uniform densification of the soil sample by static compaction. As shown in Figure 1, Jet fill tensiometers, gypsum blocks and porous tips were located at elevations 900, 700, 500, 300, $100 \mathrm{~mm}$ above the datum level. Standpipes and a manometer board were made to check positive pore water pressure inside the column and to find the location of water table.

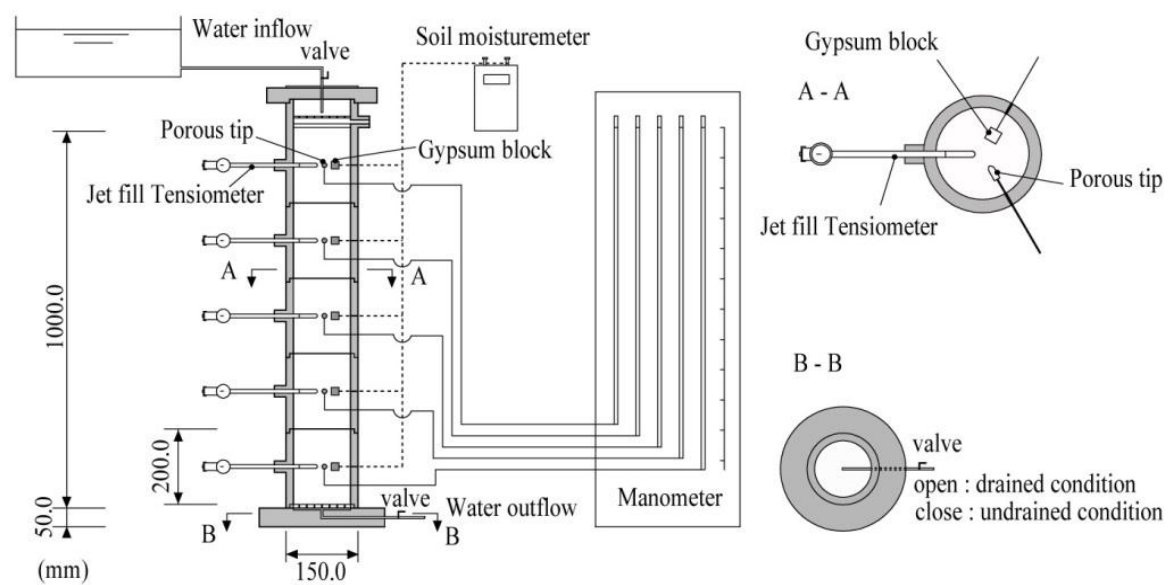

Figure 1. Schematic diagram of the column apparatus

The soil column was subjected to simulated rainfalls that $5 \mathrm{~mm}$ constant head of water was applied to the top of the column. The water was supplied from a water tank connected to the upper plate. The discharge of water from the column was controlledby the drainage valve located at the bottom plate of the column.Jet filltensiometers(Soil Moisture Inc.) (Fig. 2a) wereinserted into the column to monitor negative pore water pressure changesduring the infiltration process.In order to measure water content, Gypsum blocks (Fig. 2b) and a Soil Moisture meter (Fig. 2c) were used. Gypsum blocks that embedded electrodes are buried in the soil and the electrical current through the block is measured by the soil moisture meter.
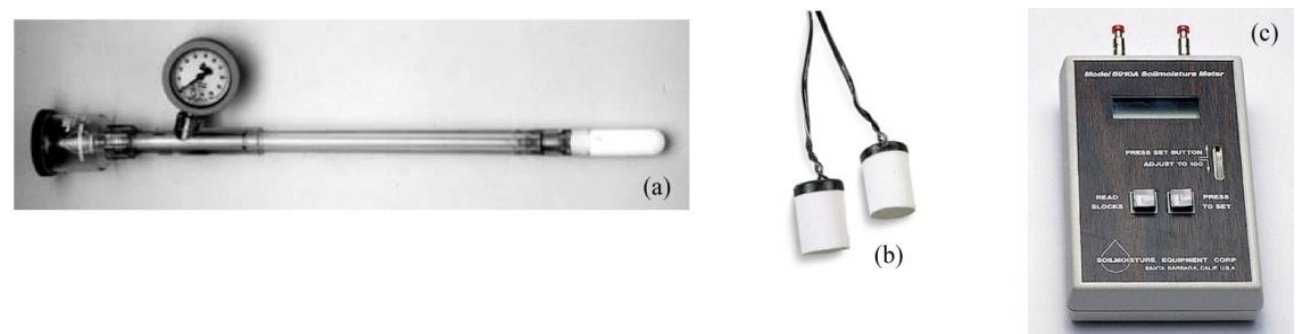

Figure 2.Test equipments (a)Jet fill tensiometer, (b) Gypsum blocks, (c) Soil moisture meter 


\section{SOIL PROPERTIES}

The sample for this experiment was obtained from the mountain area in Seong-whan, Korea. The site where the soil sample was acquired has experienced extensive level of landslide. The soil classification test (ASTM D-2487) was conducted on the soil sample followingthe Unified Soil Classification System and the soil was classified as Silty Sand (SM). The saturated permeability $\left(\mathrm{k}_{\mathrm{s}}\right)$ of the soil was determined by the ASTM D-2434 $\left(\mathrm{k}_{\mathrm{s}}=1.3 \times 10^{-5} \mathrm{~cm} / \mathrm{sec}\right)$. The water content characteristic curve defines the relationship between water content and suction in unsaturated soil. This function was determined using a Tempe pressure cell test (ASTM D-6836) for the soil sample. The sample used in the Tempe pressure cell was prepared by applying static compaction to the soil sample in a tubular frame with a diameter of 3.5centimeters and height of 2 centimeters. To obtain the water content characteristics of the soil sample, the tests were performed with pressure ranging from zero to $500 \mathrm{kPa}$. The water content characteristic curve was accurately determined by weighing the complete cell at pressure equilibrium points. Figure 3.illustrates the Tempe pressure cell and the obtained water content characteristic curve is presented in Figure 4.

Figure 3.Tempe pressure cell

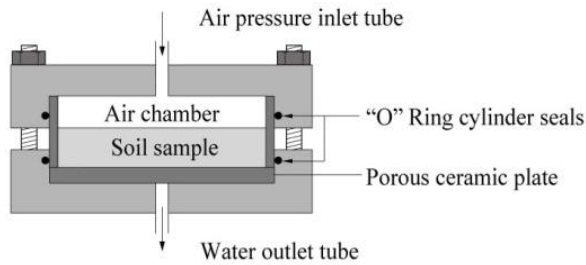

The finite element seepage program SEEP/W provides three different methods that can be used to calculate unsaturated hydraulic conductivity functions based on water content characteristic curves of soils.The methods were proposed by Fredlundet al.[3], Green and Corey [4] and Van Genuchten[10]respectively. The hydraulic conductivity curves that estimated from the three different methods using the water content characteristic curve obtained fromthe Tempe pressure cell tests are shown in Figure 4.
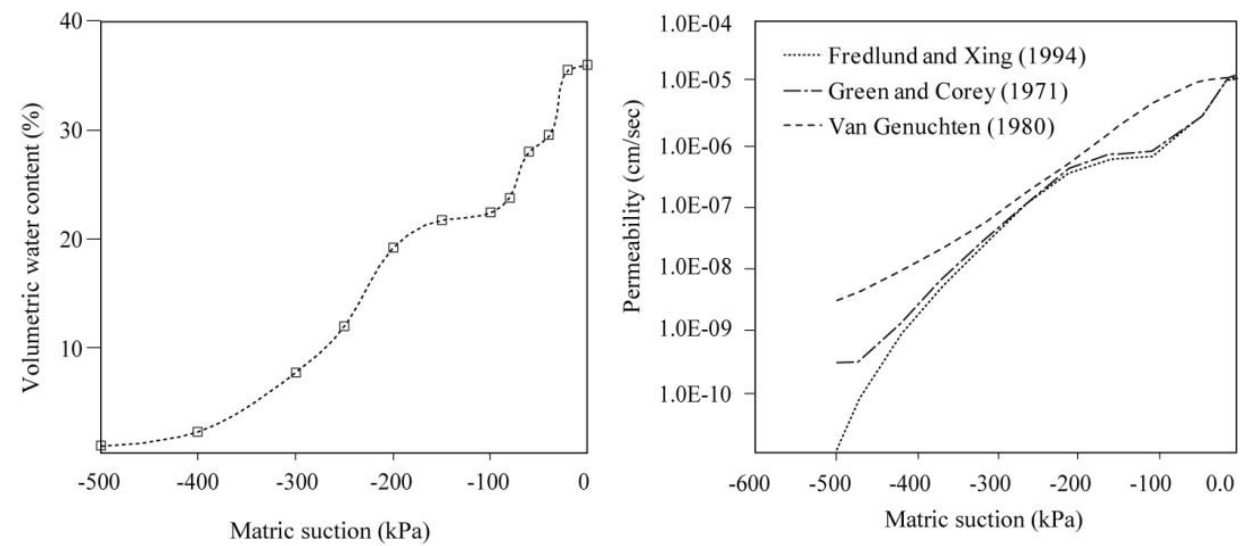

Figure 4.Water content characteristic curve from Tempe pressure cell test (left) and unsaturated hydraulic conductivity curvescalculated by SEEP/W (right) 


\section{TEST PROCEDURE AND RESULTS}

The column test process was divided into two stages, namely, the drained process and the undrained process. The specimen was compacted to a dry density of $1,600 \mathrm{~kg} / \mathrm{m}^{3}$ and water content of $10 \%$ prior to the start of the infiltration. In the drained stage, the wetting front advanced downward the columnunder constant head of water supply to the top of the column. Then, when the wetting front reached the bottom of the column and discharged through the drainage valve at the bottom, the drainage valve was closed. In the undrained stage, after the valve was closed, the measurement continued until the water table reached the top of the column. As results of the three sets of tests, during the drained process, the time it took for the wetting front to hit the bottom was from 8.5 hours to 10 hoursin the experiment.

The degree of saturation versus time was indirectly obtained by the moisturemeter readings (Fig.5(a)). The readings indicated the electrical resistance in the installed Gypsum blocks. The degree of saturation was calculated using the water content obtained from the relation between water content and the electrical resistance in Gypsum blocks. During infiltration process, the initial degree of saturation was $40 \%$ andthe value rapidly varied afterthe wetting front passed by Gypsum blocks.It was also observed that the degree of saturation at the later part of the progression of the wetting front fell far short of 100 percent. This is shown to give good agreement with the result of column experiments performed by Houston and Houston[5].

During the column wetting, the negative pore pressure gradually increased over time. Tensiometers responded promptly when the wetting front reached to the location of each Tensiometer. The suction measured at Tensiometers rose from the initial value $-25 \mathrm{kPa}$ to zero. It should be noted that this dramatic change in negative pore pressure was related in the increased water content. On the other hand, during the undrained process, total head was dramatically increased in the beginning of the test at the bottom of the column (Fig.5(b)). Pressure heads obtained from standpipes readings were used to calculate total heads. After 8.5 hours, when the drainage valve was closed, the pore water pressure at the floor skyrocketed from a negative value.It can be noted that the rapid development of a perched water table is attributed to this phenomenon.
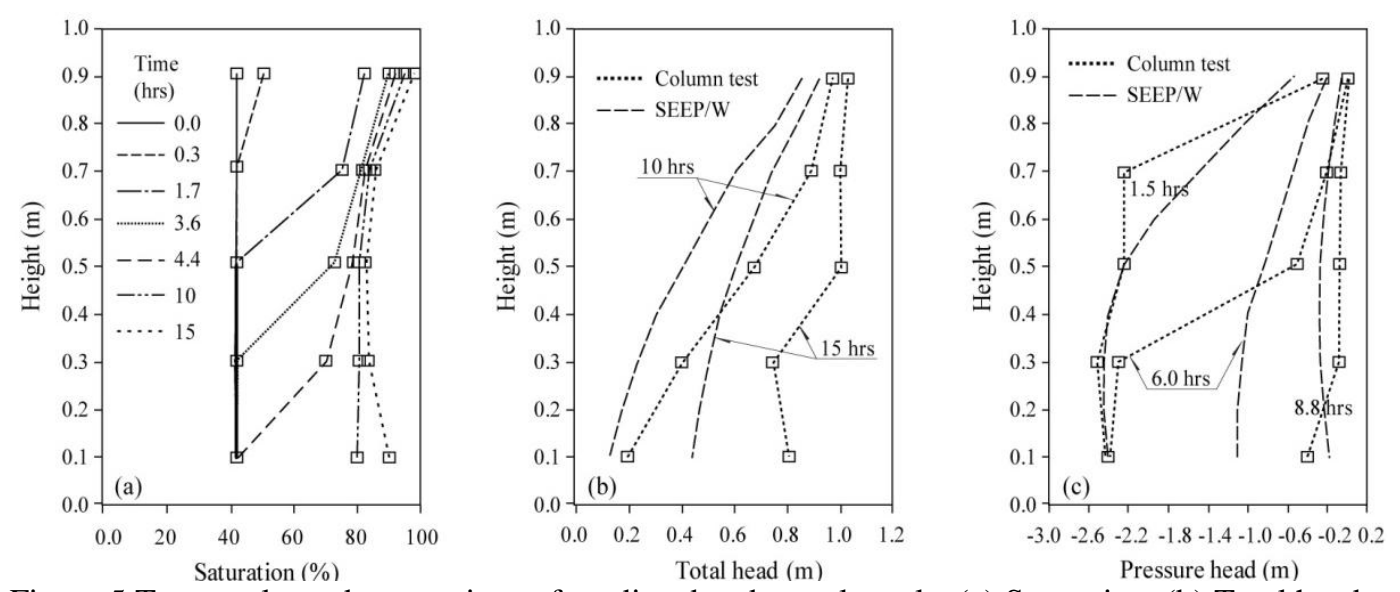

Figure 5.Test results and comparison of predicted and actual results (a) Saturation, (b) Total head, (c) Pressure head. 
Furthermore, it was also observed that the water table in standpipes at each elevation started to rise even before the drainage valve was closed. It can be explained that the error occurred from the trapped air released through a porous tip. Fredlund[2] elaborated the influence of air on the flow state of unsaturated soil : air remains at a continuous state in unsaturated soil when it's the degree of saturation is not more than 85 percent and begins to flow when changed air pressure or water compresses pores.

\section{NUMERICAL ANALYSIS}

The numerical analysis of vertical infiltration in the soil column was performed using the finite element code SEEP/W (Geostudio, 2004). The numerical model was composed of total number of 60 elements. The unsaturated conductivity curve proposed by Fredlundet al. [4] was used to the simulation. In order to assign infiltration, theconstant head $(\mathrm{H}=1.0 \mathrm{~m})$ boundary was applied to the top of the column while the free water boundary (zero pressure head) was located at the bottom level. For a transient analysis, the initial total head was defined along the column considering initial negative pore water pressure $(-25.0 \mathrm{kPa})$ in the experiment.

The numerical data in Figure 5(c) shows that the suction head gradually increased over time. In comparison with the measurement results, it can be mentioned that in the whole process of infiltration, the numerical analysis was consistent with the experiment result. Furthermore, the pore pressure distributions at 1.5 hours and 8.8 hours were shown to give good agreement with Tensiometer readings. The results of numerical analysis are presented in terms of pressure head versus depth as shown in Figure 6.

By contrast with the change of negative pore pressure, the distribution of total heads differed from the experimental data in the undrained process (Fig.5(b)). After 15.0 hours, no increase in hydraulic head was shown on the manometer due to the stagnation of infiltration in the experiment while gradual increase of total head was observed in numerical analysis. Consequently, the results of the undrained process in the experiment disagreed with those in the numerical analysis, which excluded the effect of internal air.

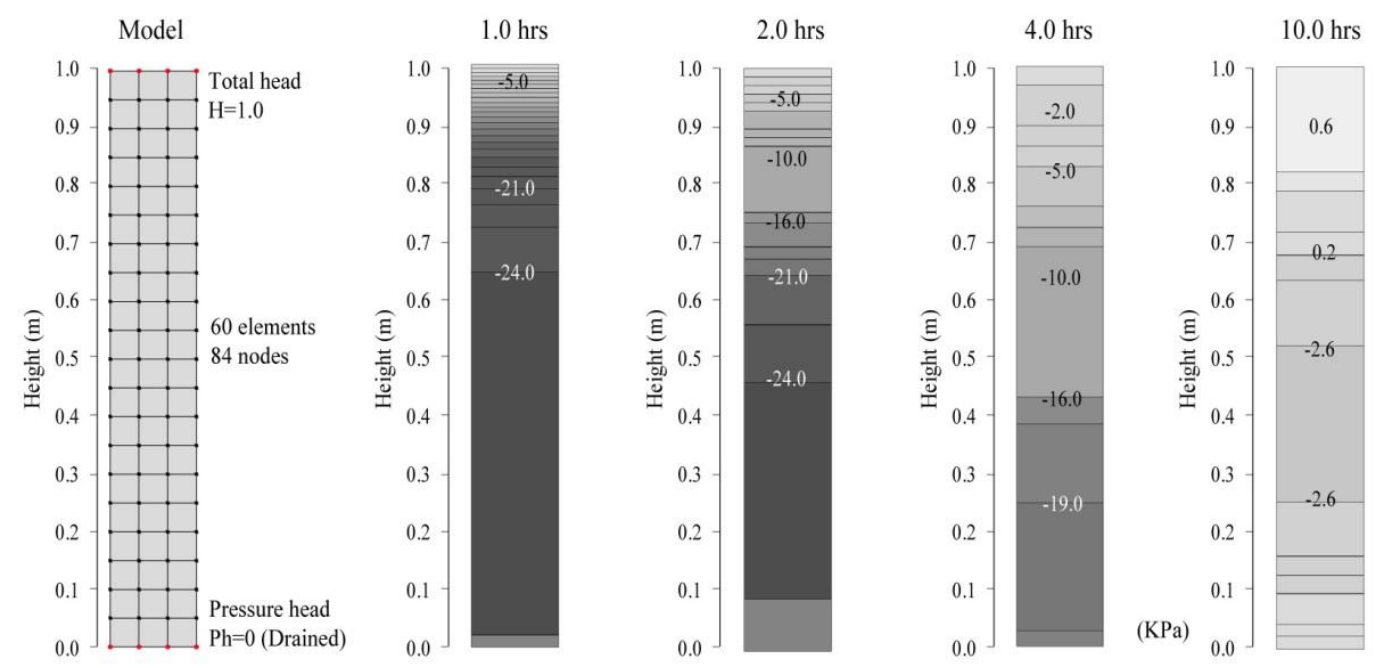

Figure 6.Numerical analysis model and pore pressure distributionover time (SEEP/W) 


\section{CONCLUSION}

The column testof unsaturated infiltration was conducted on residual soil and numerical analysis was performed to compare with the experimental study. The test results showed that, during the infiltration, the soil column was not fully saturated over time. It was also observed that the dramatic rise of pore pressure was developed at lower part of the column in the beginning of undrained process. This rapid increase of pore water pressure can be explained as the development of a perched water table.According to the both experimental and numerical tests results, it can be concluded that the change of negative pore water pressure responded sensitively when the wetting front reached to the each measuring position. Further, the negative pore pressure profiles by numerical analysis were consistent with the results obtained from the column tests. On the contrary, the profile of positive pore water pressure in the undrained test differed from those in the numerical analysis due to the effect of internal air.

\section{REFERENCES}

[1] Alonso, E.E. and Batlle, F., "Construction and impoundment of an earth dam application of the coupled flow deformation analysis of unsaturated soils", ICMS, Modern issues in Nonsaturated soils, (1995), pp 357-396.

[2] Fredrund, D.G. and Rahardjo, H., "Soil Mechanics for Unsaturated Soil”, John Wiley \& Sons, New York, (1993).

[3] Fredlund, D.G.,Xing, A. and Huang, S.,'Predicting the permeability function for unsaturated soils using the soil-water characteristics curve", Can. Geotech. J, Vol.31, (1994),pp 533-546.

[4] Green, R.E. and Corey,J.C.,"Calculation of Hydraulic conductivity : A further evaluation of some predictive methods"'Proc.Soil Science Society of America, Vol.35,(1971),pp 3-8.

[5] Houston, W.N. and Houston, S.L., "Infiltration studies for unsaturated soils ",Proc. $1^{\text {st }}$ Int. Conf. Unsaturated Soils ,Paris, France, Vol. 2, (1995), pp869-875.

[6] Krahn, J.,"Seepage modeling with SEEP/W",GEO-SLOPE International, Ltd. (2004)

[7] Kisch,M.,"The theory of seepage from clay-blanketed reservoirs" Geotechnique,Vol.9.(1959)

[8] Krahn,J.,Fredlund, D.G. and Klassen, M.J.,'Effect of soil suction on slope stability at Notch Hill” Can. Geotech. J, Vol.26, (1989),pp269-278.

[9] Rahardjo, H., Lim, T.T., Chang, M.F., and Fredlund, D.G., "Shear-strength characteristics of a residual soil", Can. Geotech. J, Vol.32, (1995),pp60-77.

[10] Van Genuchten,M.Th.,"A closed-form equation for predicting the hydraulic conductivity of unsaturated soils",Soil Science Society of America Journal 44,(1980),pp 892-898. 